\title{
ACKR1 Gene Mutation
}

National Cancer Institute

\section{Source}

National Cancer Institute. ACKR1 Gene Mutation. NCI Thesaurus. Code C153229.

A change in the nucleotide sequence of the ACKR1 gene. 